\title{
Peningkatan Pengetahuan Masyarakat tentang Pencegahan Covid-19 di Desa Bambu Kabupaten Mamuju
}

\author{
Akbar Nur ${ }^{1}$, I Kadek Dwi Swarjana ${ }^{2}$ Marlin Eppang ${ }^{3}$, Nini Sahrianti ${ }^{4}$, Wita Oileri Tikirik ${ }^{5}$. \\ ${ }_{1,2,3}$ Program Studi Ilmu Keperawatan, STIKes Andini Persada Mamuju \\ ${ }^{4,5}$ Program Studi Ilmu Farmasi, STIKes Andini Persada Mamuju \\ Email: akbarskep@gmail.com
}

Submitted : 12/07/2021

Accepted: 23/01/2022

Published: 28/01/2022

\begin{abstract}
Corona Virus or known as COVID-1 9 has now spread to various countries in the world. The World Health Organization (WHO) has declared COVID-19 a global emergency. The government has made efforts to prevent the spread of Covid-19, namely by socializing $3 M$ and $3 T$. The term $3 M$ is a health protocol that every individual needs to do to avoid contracting Covid-19, namely wearing masks, washing hands, and keeping a distance. On the other hand, to identify residents who have been exposed to Covid-19, the government has termed $3 T$ efforts, namely testing (examination), tracing (contact tracing), and treatment. The main steps that the community can take to reduce and anticipate the spread of Covid-19 are the use of masks, covering the mouth and nose when sneezing or coughing, washing hands with soap or disinfection. The purpose of this community service activity is to increase public knowledge about the prevention and implementation of health protocols during the COVID-19 pandemic. The form of activities in community service carried out by STIKES lecturer Andini Persada Mamuju by conducting health education, distributing masks, and distributing hand sanitizers. The lack of public awareness and knowledge regarding Covid-19 can be overcome by providing information in the form of health education about the importance of implementing health protocols. . This step is something that must always be applied by the whole community, especially the people of the Bamboo Village, Mamuju Regency. Information and education must continue to be provided to the public, as well as carry out supervision so that people want to implement healthy lifestyle behaviors to prevent the spread of Covid-19. Socialization activities in the form of health education, distribution of masks, hand sanitizers are one effective way to educate the public.
\end{abstract}

Keywords: covid19, education, health protokol

\begin{abstract}
Abstrak
Corona Virus atau dikenal dengan COVID-19 saat ini telah menyebar ke berbagai Negara di dunia. World Health Organisation (WHO) telah menyatakan COVID-19 merupakan kegawat daruratan Global. Pemerintah melakukan upaya pencegahan penyebaran Covid-19, yaitu dengan sosialisasi 3M dan 3T. Istilah 3M merupakan protokol kesehatan yang perlu dilakukan setiap individu agar tidak tertular Covid-19, yakni memakai masker, mencuci tangan, dan menjaga jarak. Di sisi lain, untuk mengidentifikasi warga yang terpapar Covid-19, pemerintah mengistilahkan upaya 3T, yakni testing (pemeriksaan), tracing (penelusuran kontak), dan treatment. Langkah-langkah utama yang dapat dilakukan masyarakat agar dapat mengurangi dan mengantisipasi penyebaran Covid-19, yaitu seperti penggunaan masker, menutup mulut dan hidung saat bersin ataupun batuk, mencuci tangan dengan menggunakan sabun atau desinfeksi. Tujuan kegiatan pengabdian masyarakat ini untuk meningkatkan pengetahuan masyarakat tentang pencegahan dan pelaksanaan protokol kesehatan selama pandemi covid-19. Bentuk kegiatan dalam pengabdian masyarakat yang dilakukan oleh dosen STIKES Andini Persada Mamuju dengan melakukan penyuluhan kesehatan, pembagian masker dan pembagian hand sanitizer. Kurangnya kesadaran dan pengetahuan masyarakat terkait Covid-19 dapat diatasi dengan memberikan informasi berupa penyuluhan kesehatan tentang pentingnya menerapkan protokol kesehatan. . Langkah ini merupakan hal yang harus selalu diterapkan oleh seluruh masyarakat khususnya masyarakat Desa Bambu Kabupaten Mamuju. Informasi dan edukasi harus terus diberikan kepada masyarakat, serta melakukan
\end{abstract}


pengawasan agar masyarakat mau menerapkan perilaku hidup sehat untuk mencegah penyebaran Covid-19. Kegiatan sosialisasi berupa pendidikan kesehatan, pembagian masker, hand sanitizer merupakan salah satu cara yang efektif dilakukan untuk mengedukasi masyarakat.

Kata Kunci: Covid-19, edukasi, protokol kesehatan

\section{PENDAHULUAN}

Corona Virus atau dikenal dengan COVID-19 saat ini telah menyebar ke berbagai Negara di dunia. World Health Organisation (WHO) telah menyatakan COVID-19 merupakan kegawat daruratan Global atau pandemic pada tanggal 11 maret 2020. Pandemic COVID-19 di Indonesia terus mengalami peningkatan yang sangat significant disetiap bulannya (Djalante et al., 2020; Yesni, 2021)

Prevalensi Covid-19 per tanggal 06 Juni 2021, secara global terdapat 223 negara yang mengalami Covid-19, terkonfirmasi sebanyak 172.630.637 positif Covid-19, dan yang meninggal sejumlah 3.718.683 orang. Di Indonesia, yang terkonfirmasi positif Covid-19 sejumlah 1.856.038 orang, sembuh sejumlah 1.705.971 orang, dan meninggal sejumlah 51.612 orang. Jumlah prevalensi pasien Covid-19 di Provinsi Maluku sejumlah 7.793 (0,4\%) (Hardiani et al., 2021).

Kehadiran Covid-19 tentu berdampak pada permasalahan sosial dan terjadi hampir di seluruh dunia, karena pandemic Covid-19 yang merajalela kondisi dunia menjadi tidak stabil, tidak hanya mengatasi warga yang terpapar virus mematikan tersebut. Pemerintah melakukan upaya pencegahan penyebaran Covid-19, yaitu dengan sosialisasi $3 \mathrm{M}$ dan $3 \mathrm{~T}$. Istilah $3 \mathrm{M}$ merupakan protokol kesehatan yang perlu dilakukan setiap individu agar tidak tertular Covid-19, yakni memakai masker, mencuci tangan, dan menjaga jarak. Di sisi lain, untuk mengidentifikasi warga yang terpapar Covid-19, pemerintah mengistilahkan upaya 3T, yakni testing (pemeriksaan), tracing (penelusuran kontak), dan treatment (perawatan/isolasi) (Siringoringa, 2021).
Sesuai informasi dari WHO dan Kementerian Kesehatan yang menyatakan bahwa Covid-19 menyebar secara cepat melalui percikan droplet baik saat bersin/batuk maupun saat berbicara. Memakai masker menjadi salah satu cara efektif untuk menahan droplet yang menyebar saat seseorang sedang berbicara dan bersin atau batuk (Asmar, Sunanda, 2021). Terlebih masih ada orang tanpa gejala (OTG) di sekitar masyarakat yang belum melakukan isolasi dengan baik. Sehingga mewajibkan masyarakat memakai masker adalah upaya terbaik untuk menurunkan risiko penularan Covid-19 (Rizqi Aprilia, 2020). Selain memakai masker, menjaga jarak dan mencuci tangan juga turut menurunkan risiko penularan Covid-19, karena jika menerapkan cuci tangan pakai sabun, risiko penularan turun dari $35 \%$ menjadi $65 \%$ (Budiarti et al, 2021). Memakai masker kain menurunkan risiko penularan menjadi $45 \%$, dengan memakai masker bedah risiko penularan turun 70\% (Mutia, Otik, 2020). Menjaga jarak minimal 1 meter dapat menurunkan risiko penularan hingga $85 \%$ (Nur, 2020). Maka, dengan menggabungkan memakai masker dengan benar, menjaga jarak dan mencucui tangan dengan sabun, risiko penularan Covid-19 semakin rendah.

Langkah-langkah utama yang dapat dilakukan masyarakat agar dapat mengurangi dan mengantisipasi penyebaran Covid-19, yaitu seperti penggunaan masker, menutup mulut dan hidung saat bersin ataupun batuk, mencuci tangan dengan menggunakan sabun atau desinfeksi dengan pembersih tangan yang mengandung setidaknya $60 \%$ alkohol, menghindari kontak dengan orang yang terinfeksi, menjaga jarak dari orang-orang, dan menahan diri dari menyentuh mata, hidung, 
dan mulut dengan tangan yang tidak dicuci (Mustopa, Budiman, 2021).

Berdasarkan fenomena yang ada pada masyarakat Desa Bambu Kabupaten Mamuju Provinsi Sulawesi Barat, bahwa kesadaran masyarakat terhadap pentingnya menerapkan protokol kesehatan masih rendah, seperti saat bepergian tidak menggunakan masker, tidak mencuci tangan, dan tidak menjaga jarak. Selain itu juga munculnya stigma di kalangan masyarakat bahwa Covid-19 tidak ada dan hanya konspirasi politik, sehingga tidak perlu dikhawatirkan.

Berdasarkan kondisi terkait pencegahan dan kepatuhan masyarakat Desa Bambu Kabupaten Mamuju yang masih rendah terhadap pencegahan COVID-19. Maka kami dari dosen STIKES Andini Persada Mamuju melakukan salah satu dari kegiatan tri dharma perguruan tinggi yaitu melakukan pengabdian masyarakat terkait dengan peningkatan Pengetahuan masyarakat tentang pencegahan COVID-19 di Desa Bambu Kabupaten Mamuju.

\section{TARGET DAN LUARAN}

Target pada kegiatan pengabdian masyarakat ini adalah petugas Puskesmas Binanga, Petugas Kantor Desa dan masyarakat Desa Bambu Kabupaten Mamuju. Adapun luaran tambahan pada kegiatan ini adalah terjalinya kerjasama antara Puskesmas Bambu dan Desa Bambu dengan STIKES Andini persada Mamuju untuk melakukan sosialisasi/edukasi terkait pencegahan COVID-19 dan kegiatan ini diterbitkan pada jurnal pengabdian masyarakat

\section{METODE PELAKSANAAN}

Pada pelaksanaan pengabdian masyarakat ini dilakukan dengan beberapa tahapan yaitu; melakukan koordinasi dengan Lembaga Satuan Inovasi Riset dan Pengabdian Masyarakat STIKES Andini
Persada untuk melakukan persuratan ke Dinas Kesehatan Kabupaten Mamuju perihal Permohonan izin pengabdian masyarakat pada Puskesmas Bambu dan Wilayah kerja puskesmas Bambu di Desa Bambu. Dengan nomor surat: 010/SIR-PMSTIKAP/SP/VII/2020 dan nomor surat izin/rekomendasi dari Dinas Kesehatan Kabupaten Mamuju yaitu: 440/515/VII/2020/Dinkes. setelah kegiatan pelaksanaan Pengabdian dosen STIKES Andini Persada Mamuju mendapat izin/rekomendasi dari Kepala dinas kesehatan Kabupaten Mamuju. Kegiatan pengabdian ini dilaksanakan selama 3 hari yaitu tanggal 22-24 Juli 2020 di Wilayah kerja Puskesmas Bambu di Desa Bambu. Adapun bentuk kegiatannya adalah Health Education, Pembagian masker dan Hands Sanitizer.

\section{HASIL DAN PEMBAHASAN}

Kegiatan pengabdian masayarakat yang berjudul "peningkatan Pengetahuan masyarakat tentang pencegahan COVID-19 di Desa Bambu Kabupaten Mamuju" yang dilakukan selam 3 hari di Wilayah kerja Puskesmas Bambu di Desa Bambu yaitu hari Rabu-Jumat. Kegiatan ini melakukan kunjungan ke Puskesmas Binanga dan sekaligus memberikan pembagian masker dan hands sanitizer kepada perawat, dokter, dan petugas kesehatan yang ada di Puskesmas Bambu. Berikutnya mengunjungi kantor Desa Bambu guna untuk memberikan pembagian masker, dan hands sanitizer. Dan kegiatan berikutnya adalah memberikan edukasi kepada masyarakat desa bambu terkait pentingnya menjaga dan meningkatkan pencegahan penularan COVID-19 dengan mengikuti himbauan yang telah ditetapkan oleh pemerintah baik pusat maupun daerah., selain pemberian edukasi kepada masyarakat juga dilakukan pemberian masker dan hand sanitizer. dalam kegiatan ini juga melibatkan mahasiswa dan 
pengurus Badan Eksekutif Mahasiswa (BEM) STIKES Andini Persada Mamuju. Kegiatan pengabdian masyarakat telah berhasil dilakukan secara kondusif tanpa ada pengumpulan massa sehingga kegiatan sosialisasi dapat berjalan lebih efektif dan efisien.

Berikut terdapat beberapa foto yang berhasil didokumentasikan pada saat kegiatan berlangsung:

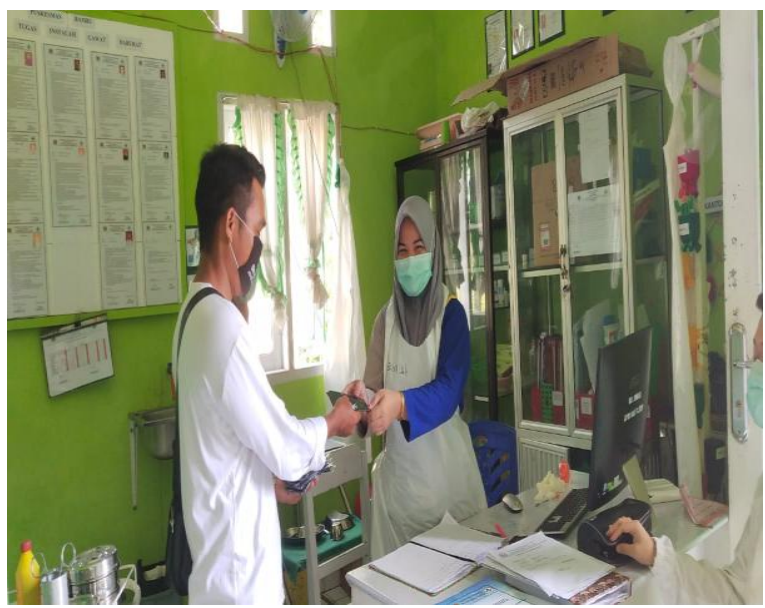

Gambar 1. Pembagian masker dan hand sanitizer kepada dokter, perawat dan petugas kesehatan lainnya di Puskesmas Binanga.

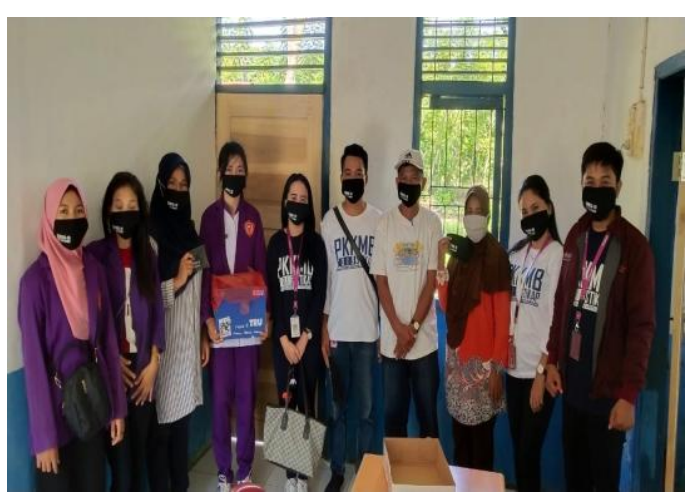

Gambar 2. Edukasi pencegahan Covid-19 dan membagikan masker serta hand sanitizer kepada pasien yang sedang berobat di Puskesmas Bambu
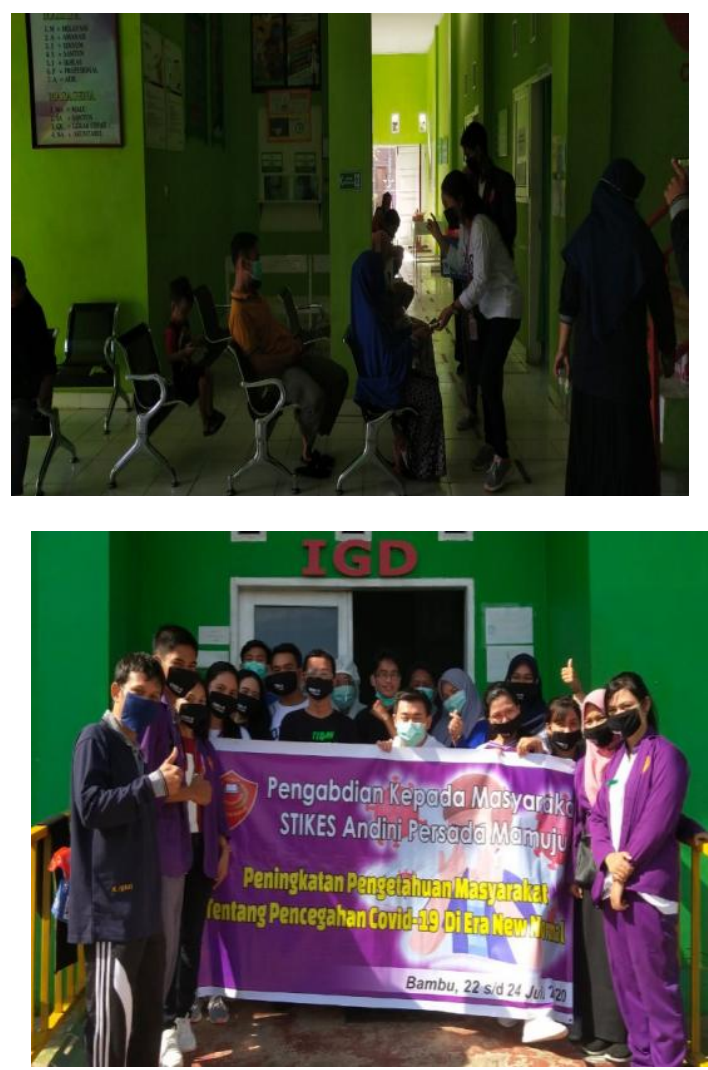

Gambar 3. Memberikan Paket hand sanitizer dan masker di kantor Desa Bambu untuk dibagikan kepada pegawai kantor Desa dan masyarakat Desa Bambu

WHO mengemukakan bahwa kegiatan sosialisasi tentang pencegahan penyebaran Covid-19 merupakan salah satu upaya yang dapat dilakukan (Nugrawati, Ekawati and Wijaya, 2020). Sesuai informasi dari WHO dan Kementerian Kesehatan yang menyatakan bahwa Covid19 menyebar secara cepat melalui percikan droplet baik saat bersin/batuk maupun saat berbicara. Memakai masker menjadi salah satu cara efektif untuk menahan droplet yang menyebar saat seseorang sedang berbicara dan bersin atau batuk (Asmar, Sunanda, 2021). Terlebih masih ada Orang Tanpa Gejala (OTG) di sekitar masyarakat yang belum melakukan isolasi dengan baik. Sehingga mewajibkan masyarakat memakai masker adalah upaya terbaik untuk menurunkan risiko penularan Covid-19 
(Rizqi Aprilia, 2020). Selain memakai masker, menjaga jarak dan mencuci tangan juga turut menurunkan risiko penularan Covid-19, karena jika menerapkan cuci tangan pakai sabun, risiko penularan turun dari 35\% menjadi 65\% (Budiarti et al, 2021). Memakai masker kain menurunkan risiko penularan menjadi $45 \%$, dengan memakai masker bedah risiko penularan turun 70\% (Mutia, Otik, 2020). Menjaga jarak minimal 1 meter dapat menurunkan risiko penularan hingga $85 \%$ (Nur, 2020). Maka, dengan menggabungkan memakai masker dengan benar, menjaga jarak dan mencucui tangan dengan sabun, risiko penularan Covid-19 semakin rendah.

Pengetahuan dan tindakan yang nyata dari pemerintah dan masyarakat terkait PHBS akan mampu menurunkan jumlah kasus COVID-19, sehingga masa pandemi COVID-19 dapat berakhir dengan cepat (Nugrawati, Ekawati and Wijaya, 2020). Peran pemerintah harus tegas dalam menerapkan sanksi pidana dan pidana denda sebagai alternatif untuk membuat masyarakat jera, teredukasi dan sebagai sarana pengendalian sosial Berdasarkan fenomena tersebut, hal ini perlu disadari, pemerintah tidak bisa kerja sendiri. Perlu Gerakan massif melibatkan semua komponen masyarakat, terutama tokohtokoh nonformal yang dapat memberi pengaruh langsung ke masyarakat (Alfiana, Wulandari, 2021).

Sejalan dengan hal di atas ada beberapa kebijakan yang telah dilakukan oleh Pemerintah sebagai upaya memutuskan rantai penyebaran Covid-19 tersebut tentunya perlu diapresiasi karena hal tersebut merupakan bagian dari kepedulian pemerintah terhadap rakyatnya (Yostuanti, 2021). Selain itu, masyarakat juga memiliki peran penting dalam memutus mata rantai penularan COVID-19 agar tidak menimbulkan sumber penularan baru/cluster pada tempat-tempat dimana terjadinya pergerakan orang, interaksi antar manusia dan berkumpulnya banyak orang
(Rahayu, 2020). Masyarakat harus dapat beraktivitas kembali dalam situasi pandemi COVID-19 dengan beradaptasi pada kebiasaan baru yang lebih sehat, lebih bersih, dan lebih taat, yang dilaksanakan oleh seluruh komponen yang ada di masyarakat serta memberdayakan semua sumber daya yang ada. Peran masyarakat untuk dapat memutus mata rantai penularan COVID-19 (risiko tertular dan menularkan) harus dilakukan dengan menerapkan protokol kesehatan melalui perlindungan kesehatan individu dan perlindungan kesehatan masyarakat) (Asmar, Sunanda, 2021).

Dengan demikian kegiatan kampanye, sosialisasi, maupun penyuluhan terkait program $3 \mathrm{M}$ sangat penting untuk dilakukan khususnya kepada masyarakat di desa sehingga informasi dan sosialisasi terkait Covid-19 dapat diketahui secara merata. Selain itu, BNPB mengatakan bahwa perubahan perilaku untuk menangani permasalahan penularan COVID-19, yaitu dengan mendorong percepatan perubahan perilaku masyarakat agar secara konsisten menjalankan 3M. Perubahan perilaku manusia terjadi akibat dua dorongan, yakni dorongan dari dalam diri sendiri dan dorongan dari luar. Idealnya, perubahan perilaku berasal dari kesadaran dalam diri.

\section{KESIMPULAN DAN SARAN}

\section{Kesimpulan}

Kegiatan sosialisasi yang telah dilaksanakan untuk memutus rantai penularan Covid-19, salah satunya dengan terus menerus menerapkan 3M kepada masyarakat. Kegiatan pembagian masker, hand sanitizer, serta memberi edukasi kepada masyarakat tentang cara dan pentingnya mencegah COVID-19 dan penularannya, sehingga sangat dihimbauan kepada seluruh masyarakat untuk patuh menggunakan masker, menjaga jarak dan mencuci tangan. Langkah ini merupakan hal yang harus selalu diterapkan oleh 
seluruh masyarakat khususnya masyarakat Desa Bambu Kabupaten Mamuju. Informasi dan edukasi harus terus diberikan kepada masyarakat, serta melakukan pengawasan agar masyarakat mau menerapkan perilaku hidup sehat untuk mencegah penyebaran Covid-19. Kegiatan sosialisasi berupa pendidikan kesehatan, pembagian masker, hand sanitizer merupakan salah satu cara yang efektif dilakukan untuk mengedukasi masyarakat.

\section{Saran}

Diharapkan peran pemerintah, institusi, masyarakat maupun instansi terkait di Kabupaten Mamuju khsusnya Desa Bambu dapat bekerjasama dan berkolaborasi dalam peningkatan pencegahan COVID-19.

\section{UCAPAN TERIMAKASIH}

Kami dari tim pengabdian masyarakat dosen STIKES Andini Persada mengucapkan terimakasih kepada seluruh pihak yang telah terlibat dan mendukung dalam proses kegiatan yang kami lakukan. Khususnya kepada Dinas Kesehatan Kabupaten Mamuju, Puskesmas Bambu, Desa Bambu dan seluruh masyarakat Desa Bambu yang telah mendukung kegiatan pengabdian masyarakat yang kami lakukan.

\section{DAFTAR PUSTAKA}

Alfiana, Wulandari, A. (2021) 'Upaya Penguatan Ketahanan Masyarakat Desa Sirnoboyo di Masa Pandemi Covid-19', Altifani Penelitian dan Pengabdian kepada Masyarakat, 1(2), pp. 149-155. doi: 10.25008/altifani.v1i2.142.

Asmar, Sunanda, N. (2021) 'Pengaruh Pandemi Covid-19 bagi Masyarakat Karau Barat Kabupaten Bangka Tengah', Dharma Pengabdian Perguruan Tinggi, 1, pp. 11-16.

Budiarti et al (2021) 'Edukasi Kesehatan Pencegahan Covid-19 dalam
Perubahan Pengetahuan Masyarakat Kalipecabean Sidoarjo', Journal of Chemical Information and Modeling, 53(9), pp. 1689-1699.

Djalante, R. et al. (2020) 'Review and analysis of current responses to COVID-19 in Indonesia: Period of January to March 2020', Progress in Disaster Science. Elsevier, 6, p. 100091.

Hardiani, D. et al. (2021) 'Sosialisasi Pentingnya Penerapan 3M di Era New Normal Desa Riding Panjang', Jurnal Pengabdian Masyarakat Indonesia, 1(3), pp. 85-90. doi: 10.52436/1.jpmi.9.

Mustopa, Budiman, S. (2021) 'FaktorFakotr yang Mempengaruhi Perilaku Masyarakat dengan Kepatuhan Protokol Kesehatan 3M sebagai Upaya Pencegahan Penyakit Covid19: Literature Review', Prosiding Pertemuan Ilmiah Nasional Penelitian \& Pengabdian Masyarakat II, 2(1), pp. 116-123.

Mutia, Otik, A. (2020) 'Penerapan Protokol Kesehatan Era New Normal dan Risiko Covid-19 pada Mahasiswa', Riset Informasi Kesehatan, 9(2). doi: 10.30644/rik.v8i2.460.

Nugrawati, N., Ekawati, N. and Wijaya, A. (2020) 'Pendidikan Perilaku Hidup Bersih dan Sehat Masyarakat Kelurahan Pa'bundukang Kecamatan Polombangkeng Selatan Kabupaten Takalar', Window of Community Dedication Journal, 01(02), pp. 6368.

Nur, S. \& (2020) 'Keterlibatan Warga Negara (Civil Engagement) dalam Memutus Penyebaran Covid-19', Prosiding Seminar Nasional Pendidikan FKIP Universitas Sultan Ageng Tirtayasa, 47(3), pp. 515-519. 
Rahayu (2020) 'Pemberdayaan Dukungan Keluarga dalam Meningkatkan Pemahaman Pencegahan Covid-19 di Masyarakat Jatibening', Jurnal Antara Pengmas, 3(1), pp. 150-154.

Rizqi Aprilia, S. W. (2020) 'Penerapan Protokol Kesehatan COVID-19 di Era New Normal Pada Kampung Tangguh Desa Karangdoro, Terminal Jajag, dan RTH Maron Genteng, Kabupaten Banyuwangi', Multidisciplinary Journal, 3(1), pp. 25-33.

Siringoringa, E. (2021) 'Edukasi Pencegahan Covid-19 pada Masyarakat di Desa Paenre Lompoa
Kecamatan Gantarang Kabupaten Bulukumba', Abdimas Panrita, 2(1), pp. 1-5.

Yesni, M. (2021) 'Edukasi tentang Protokol Pencegahan Covid-19 kepada Masyarakat Kelurahan Lebak Bandung Kota Jambi Corona Virus atau dikenal dengan COVID-19 saat ini telah menyebar ke', 3(2), pp. 174177.

Yostuanti, I. (2021) 'Penguatan Perilaku untuk Pencegahan Penularan Penyakit Covid-19 pada Masyarakat di Pasar Eban Kefamenanu', Pasopati, 3(2), pp. 80-83. 